\title{
Models Of Psychological Assistance Tothe Elderly
}

\author{
Johnson S.P.Siregar \\ \{jhonsonsahat@gmail.com\} \\ Postgraduate Program, Pelita Kebenaran School of Theology
}

\begin{abstract}
The senior citizens (elderly), as the final stage in the human life cycle, is part of the life process that can not be avoided and will be experienced by every individual, if they are able to reach old age. At the stage of elderly, people experience a lot of changes both physically, mentally, and along with that various functions and abilities that people previously have, such as gray hair, wrinkling facial skin, reduced vision and decrease in endurance is a reality that will occur.Changes caused by retirement require adjustment; a study of Holmes and Rahe (1967) revealed: that retirement ranks in the top 10 to cause stress. For people who experience difficulties in adjustment, changes, changes that occur in the elderly phase will cause psychological and physiological disorders where physiological disorders can lead to earlier death (premature death). Another term is retirement shock or retirement syndrome, while psychological disorders as a result of entering the elderly phase are usually stressful, frustrating and depressing.
\end{abstract}

Keywords: Mental Development Pattern, Elderly

\section{Introduction}

Aging is a natural process that cannot be prevented and is a natural thing experienced by people who are given the gift of long life, as everyone hopes to live a quiet,peaceful life, and enjoy their retirement with their beloved children and grandchildren (Hamid, 2006). Not all elderly people can enjoy such an ideal condition. The aging process still causes problems both physically, biologically, mentally and socio-economically (Nugroho, 2000). At the elderly stage, someone will experience changes in terms of physical, cognitive, and psychosocial life (Papalia, et al, 2001; Ariyanti, 2009). Darnton-Hill (1995; Oye Gureje, 2008) also highlights the importance of life expectancy and quality of life for elderly people. All of the above are consistent with the concept of WHOQOL Group (1996) which identifies four factors that affect quality of life, namely physical health factors, psychological health, social relations, and environmental factors (Rapley, 2003).

\section{Research Methodology}

This study uses a cross-sectional study method with Nonprobability Sampling technique for Purposive Sampling type in the elderly in Hargo Dedali Nursing Home that meets the inclusion and exclusion criteria of the study. The inclusion criteria in this study are: (1) Older people who live in the Dedali Hargo Nursing Home in Surabaya more than one month; (2) Aged 60 years and over; (3) Elderly dementia, deafness, psychological disorders, and decreased consciousness. Exclusion criteria in this study were: (1) Experiencing 
communication disorders; (2) Elderly people who are not willing to become respondents. The number of samples that met the criteria in this study were 19 people.

\section{Results And Discussion}

Table 1 shows that most respondents have moderate quality of life, that is as much as $58 \%$, stable psychological factors of $42 \%$, less active social factors of $42 \%$, and sufficient environmental factors of $47 \%$.

Table 1. Quality of life of elderly people, physical factors, psychological factors, social factors and elderly environmental factors.

\begin{tabular}{|c|c|c|c|c|}
\hline & Variab & & Frequency & Percentage \\
\hline \multirow[t]{5}{*}{1.} & \multicolumn{4}{|c|}{ Quality of Life } \\
\hline & - & High & 5 & 16 \\
\hline & - & Moderate & 11 & 58 \\
\hline & & Low & 3 & 16 \\
\hline & Total & & 19 & 100 \\
\hline \multirow[t]{6}{*}{2.} & \multicolumn{4}{|c|}{ Physical factor } \\
\hline & & Poor & 10 & 52 \\
\hline & - & Adequately Good & 3 & 16 \\
\hline & - & Good & 6 & 32 \\
\hline & - & Very Good & 0 & 0 \\
\hline & Total & & 19 & 100 \\
\hline \multirow[t]{6}{*}{3.} & \multicolumn{4}{|c|}{ Psychological factor } \\
\hline & - & Inadequately Stable & 5 & 26 \\
\hline & - & Adequately Stable & 6 & 32 \\
\hline & - & Stable & 8 & 42 \\
\hline & - & VeryStable & 0 & 0 \\
\hline & Total & & 19 & 100 \\
\hline \multirow[t]{6}{*}{4.} & \multicolumn{4}{|c|}{ Social factor } \\
\hline & - & Inadequately Active & 8 & 42 \\
\hline & - & Adequately Active & 7 & 37 \\
\hline & - & Active & 4 & 21 \\
\hline & - & VeryActive & 0 & 0 \\
\hline & Total & & 19 & 100 \\
\hline \multirow[t]{6}{*}{5.} & \multicolumn{4}{|c|}{ Environmental factor } \\
\hline & - & Inadequate & 2 & 11 \\
\hline & - & Moderately Adequate & 9 & 47 \\
\hline & - & Adequate & 8 & 42 \\
\hline & - & VeryAdequate & 0 & 0 \\
\hline & Total & & 19 & 100 \\
\hline
\end{tabular}

Table 1 shows the value of $\mathrm{p}=0,000$, where Ho is rejected and H1 is accepted, meaning that there are effects of physical factors on the quality of life of the elderly with the closeness of the relationship of $\mathrm{r}=0.753$, while $\mathrm{r} 2$ is 0.567 . This shows that physical factors have an effect on $56.7 \%$ of quality of life. 
Table 2. Effect of physical factors on the quality of life of elderly in Surabaya Dedali Hargo Nursing Home.

\begin{tabular}{lllllllll}
\hline \multirow{2}{*}{ Physical Factor } & \multicolumn{9}{l}{ Quality of life of elderly people } & \multicolumn{3}{c}{ Total } \\
& \cline { 2 - 7 } & Low & \multicolumn{3}{c}{ Moderate } & High & & \\
\cline { 2 - 7 } & Total & $\%$ & Total & $\%$ & Total & $\%$ & Total & $\%$ \\
\hline Poor & 5 & 26 & 5 & 26 & 0 & 0 & 0 & 52 \\
Adequately Good & 0 & 0 & 3 & 16 & 0 & 0 & 10 & 16 \\
Good & 0 & 0 & 3 & 16 & 3 & 16 & 3 & 32 \\
Very Good & 0 & 0 & 0 & 0 & 0 & 0 & 6 & 0 \\
\hline Total & 5 & 26 & 11 & 58 & 3 & 16 & 19 & 10 \\
& & & & & & & & 0 \\
\hline
\end{tabular}

Correlation coefficient (r) 0.753

Determination Coefficient $(\mathrm{r} 2)=0.567$

Significance $(\mathrm{p})=0,000$

Table 3. Effect of psychological factors on the quality of life of the elderly in Surabaya Dedali Hargo Nursing Home.

\begin{tabular}{|c|c|c|c|c|c|c|c|c|}
\hline \multirow[t]{3}{*}{ Psychological factor } & \multicolumn{6}{|c|}{ Quality of life of elderly people } & \multirow{2}{*}{\multicolumn{2}{|c|}{ Total }} \\
\hline & \multicolumn{2}{|c|}{ Low } & \multicolumn{2}{|c|}{ Moderate } & \multicolumn{2}{|l|}{ High } & & \\
\hline & Total & $\%$ & Total & $\%$ & Total & $\%$ & Total & $\%$ \\
\hline Inadequately Stable & 2 & 10 & 3 & 16 & 0 & 0 & 5 & 26 \\
\hline Adequately Stable & 3 & 16 & 3 & 16 & 0 & 0 & 6 & 32 \\
\hline Stable & 0 & 0 & 5 & 26 & 3 & 16 & 8 & 42 \\
\hline VeryStable & 0 & 0 & 0 & 0 & 0 & 0 & 0 & 0 \\
\hline Total & 5 & 26 & 11 & 58 & 3 & 16 & 19 & 100 \\
\hline
\end{tabular}

Correlation Coefficient (r) 0.814

Determination Coefficient $(\mathrm{r} 2)=0.662$

Significance $(\mathrm{p})=0,000$

Table 4. Effect of social factors on the quality of life of the elderly in Surabaya Dedali Hargo Nursing Home.

\begin{tabular}{lllllllll}
\hline Social factor & \multicolumn{9}{l}{ Quality of life of elderly people } & \multicolumn{3}{c}{ Total } \\
\cline { 2 - 7 } & \multicolumn{2}{l}{ Low } & \multicolumn{3}{l}{ Moderate } & High & & \\
\cline { 2 - 7 } & Total & $\%$ & Total & $\%$ & Total & $\%$ & Total & $\%$ \\
\hline Inadequately Active & 5 & 26 & 3 & 16 & 0 & 0 & 8 & 42 \\
Adequately Active & 0 & 0 & 6 & 32 & 1 & 6 & 7 & 38 \\
Active & 0 & 0 & 2 & 10 & 2 & 10 & 4 & 20 \\
VeryActive & 0 & 0 & 0 & 0 & 0 & 0 & 0 & 0 \\
\hline Total & 5 & 26 & 11 & 58 & 3 & 16 & 19 & 100 \\
\hline
\end{tabular}

Correlation coefficient (r) 0.704

The coefficient of determination $(\mathrm{r} 2)=0.495$

Significance $(\mathrm{p})=0,000$

Table 5. Effect of social factors on the quality of life of the elderly in Surabaya Dedali Hargo Nursing Home.

\begin{tabular}{lllllllll}
\hline Environmental factor & \multicolumn{3}{l}{ Quality of life of elderly people } & \multicolumn{2}{c}{ Total } \\
& \cline { 2 - 9 } & Low & \multicolumn{3}{l}{ Moderate } & High & & \\
\cline { 2 - 9 } & Total & $\%$ & Total & $\%$ & Total & $\%$ & Total & $\%$ \\
\hline Inadequate Moderately & 1 & 5 & 1 & 6 & 0 & 0 & 2 & 11 \\
\hline
\end{tabular}




\begin{tabular}{lllllllll}
\hline Adequate & 4 & 21 & 5 & 26 & 0 & 0 & 9 & 47 \\
Adequate & 0 & 0 & 5 & 26 & 3 & 16 & 8 & 42 \\
Very Memadai & 0 & 0 & 0 & 0 & 0 & 0 & 0 & 0 \\
\hline Total & 5 & 26 & 11 & 58 & 3 & 16 & 19 & 100 \\
\hline
\end{tabular}

Correlation coefficient (r) 0.626

The coefficient of determination $(\mathrm{r} 2)=0.392$

Significance $(\mathrm{p})=0.001$

\section{Discussion}

Based on the results of the study, most respondents had a moderate quality of life. Obtaining the value of respondents with unfavorable categories found in physical factors and social factors, sufficient categories obtained on environmental factors, and good categories obtained on psychological factors.

Quality of life is the extent to which a person can feel and enjoy experiencing all important events in life so that life becomes well (Rapley, 2003). If one can achieve a high quality of life, the life of the individual leads to a state of well-being, whereas if one experiences a low quality of life, the life of that individual leads to a state of ill-being (Brown, 2004)

\subsection{Effect of physical factors on the quality of life of the elderly in Surabaya Dedali Hargo Nursing Home.}

Based on the results of the study, elderly people will experience changes in changes in terms of physical, cognitive, and psychosocial life (Papalia, Olds, \& Feldman, 2001; Ariyanti, 2009). Optimal aging can be interpreted as a functional condition of the elderly who are in maximized condition, allowing them to enjoy a meaningful, happy, useful and qualityold age.

The physical condition that comes with getting older makes the elderly feel that less meaningful and prompting despair in the life they are living. This is a sign of low quality of life of the elderly, not allowing them to enjoy old age. Therefore, health services for the elderly population demands plenty of attention, to avoid misery in spending the rest of their lives.

\subsection{Effect of psychological factors on the quality of life of the elderly in Surabaya Dedali Hargo Nursing Home}

Based on the results of the study, psychological well-being is one of the factors that determine the quality of the elderly. Psychological factors are important factors for individuals to control all the events they experience in life. Psychological changes come from an awareness of decline and a feeling of inferiority when compared to younger people, strength, speed and skill. At the stage of the development of the elderly, the main developmental task is to understand and accept the physical and psychological changes they experience and use their life experience to adjust to physical and psychological changes. 


\subsection{Effect of social factors on the quality of life of the elderly in Surabaya Dedali Hargo Nursing Home}

Social welfare factors become one of the factors in determining a person's quality of life. Well-being measurement involves mapping the whole life and considering every event in life or the social context that is very potential to influence the quality of life of an individual. As we get older, social activities decrease. Also called "social disengagement" is a process of reciprocal resignation in the elderly and social environment (Kalish, 1976; Hurlock, 2002).

\section{Conclusion}

According to the study, a person's general physical condition will experienced a setback when entered the elderly phase, marked by the emergence of various diseases that were not experienced before at a young age. Based on the study, psychological change begins from an awareness of decline and feelings of inferiority. Compared with younger people, the main solution is to understand and accept physicaland psychological changes and spending life experiences to adjust to physical and psychological changes. Social welfare factors determine a person's quality of life. As age increases, social activities will decrease, in which there will be reciprocal resignation of the elderly in the social environment.Environmental factors in an elderly care institution help them feel supported with the available facilities, making them feel fulfilled in their lives.

\section{References}

[1] [Elvina, (2006). Quality of Life pada Lanjut Usia Studi Perbandingan pada Janda atau Duda Lansia Antara yang Tinggal di Rumah Bersama Keluarga Dengan Yang Tinggal di Panti Werdha. Tesis Universitas Katolik Indonesia Atma Jaya. Tidak dipublikasikan.

[2] Hurlock, E. B. (2002). Psikologi Perkembangan: Suatu Pendekatan Sepanjang Rentang Kehidupan. Edisi Kelima (Terjemahan). Jakarta.

[3] Mangoenprasodjo, A., dan Hidayati, S.R. (2005). Mengisi Hari Tua dengan Bahagia. Jogjakarta: Pradipta, Hal: 4, 8 .

[4] Nenk. (2010). Masalah Kesehatan Jiwa Pada Lanjut Usia, http://www.epsikologi.com/epsi/lanjutusia_detail.asp?id=182. Tanggal 14 April 2010. Jam 20.43 WIB.

[5] Ratna. (2008). Pengaruh Faktor-Faktor Kesehatan, Ekonomi dan Hubungan Sosial Terhadap Kemandirian Orang Lanjut Usia.http://www.damandiri.or.id/file/ratnasuhartini unair bab1.pdf. Tanggal 21 April 2010. Jam 09.08 WIB. 